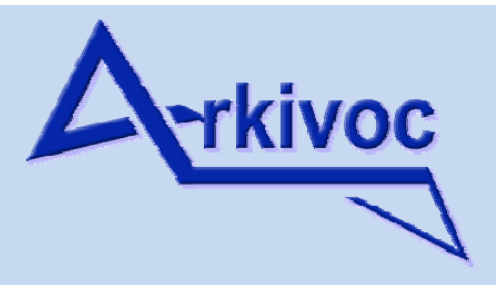

Archive for

Organic Chemistry
The Free Internet Journal

for Organic Chemistry
Paper

Arkivoc 2018, part ii, 60-71

\title{
Promotional effect of ionic liquids in the electrophilic fluorination of phenols
}

\author{
Gennady I. Borodkin, ${ }^{\mathrm{a}, \mathrm{b} *}$ Innokenty R. Elanov, ${ }^{\mathrm{a}}$ and Vyacheslav G. Shubin ${ }^{\mathrm{a}}$ \\ ${ }^{a}$ N.N. Vorozhtsov Novosibirsk Institute of Organic Chemistry, Siberian Branch of the Russian Academy of \\ Sciences, Academician Lavrent'ev Ave., 9, Novosibirsk 630 090, Russian Federation \\ ${ }^{b}$ Novosibirsk State University, Pirogov st. 2, Novosibirsk 630 090, Russia \\ E-mail: gibor@nioch.nsc.ru
}

Dedicated to Prof. Kenneth Laali on the occasion of his $65^{\text {th }}$ birthday

Received 05-10-2017

Accepted 06-28-2017

Published on line $10-15-2017$

\section{Abstract}

The influence of a stoichiometric amount of ionic liquids (IL) on the fluorination of phenols in various solvents has been studied. The fluorination of phenol, 1-naphthol and resorcinol was carried out using 1-chloromethyl4-fluoro-1,4-diazoniabicyclo[2.2.2] octane bis(tetrafluoroborate) (F-TEDA-BF 4 , Selectfluor ${ }^{\mathrm{TM}}$ ) with the formation of 2-fluoro-, 4-fluorophenol, 2-fluoro-, 4-fluoronaphthol and 4-fluoro-, 4,6-difluoro-benzene-1,3-diol as the main products. The use of a stoichiometric amount of ionic liquid as an additive results in acceleration of the reactions. The effect is most significant at low temperatures. It has been found that solvent polarity has an essential effect on the difference in yields of fluoroproducts obtained in the presence of IL and without it.
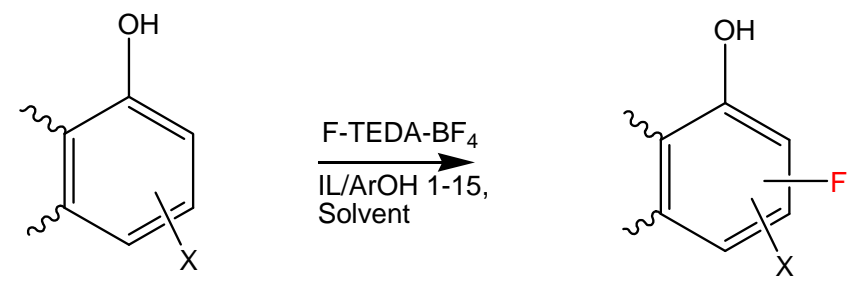

Keywords: Fluorination, phenols, ionic liquid, solvent 


\section{Introduction}

Fluorinated phenol units are frequently encountered in both biologically active ${ }^{1-4}$ and functional organic molecules. ${ }^{5,6}$ Fluoronaphthols are key intermediates for the synthesis of duloxetine metabolites. ${ }^{7}$ Highly fluorescent fluorinated fluoresceins were prepared by the reaction of fluororesorcinols with phthalic anhydride and its derivatives. ${ }^{8}$ Electrophilic fluorination of phenols is the most common synthetic strategy in the preparation of fluorinated phenols. In the last two decades a broad range of NF-reagents has started to be widely used for electrophilic fluorination of organic compounds. ${ }^{9-13}$ Among the NF-reagents Selectfluor ${ }^{\mathrm{TM}}$ is one of the most widely utilized chemical (Figure 1 ).${ }^{13}$ This reagent is a stable, easy to handle, nonhygroscopic solid which is commercially available. Reactions are typically performed in $\mathrm{MeCN}, \mathrm{CH}_{2} \mathrm{Cl}_{2}, \mathrm{CHCl}_{3}$ or $\mathrm{ClCH}_{2} \mathrm{CH}_{2} \mathrm{Cl}^{9}{ }^{9-13}$ Selectfluor ${ }^{\mathrm{TM}}$ was shown to be soluble in ionic liquids (ILs), thus ILs can be expected to act as promoters in the electrophilic fluorination of organic compounds. One of the disadvantages of ionic liquids is their high cost. Therefore, it would be attractive to use a small amount of ionic liquids with organic solvents to minimize their consumption ( $c f$. refs. ${ }^{14-18}$ ). Recently, we have studied promotional effect of ionic liquids in electrophilic fluorination of methylated uracils with Selectfluor ${ }^{\mathrm{TM}}$ in alcohols. ${ }^{19}$ The use of a stoichiometric amount of ionic liquid as an additive results in acceleration of the reaction. As a part of our program aimed at exploring the potential use of a stoichiometric amount of ionic liquid we have tried to use similar catalytic strategy for fluorination of phenol, 1-naphthol and resorcinol in various solvents. In this work, we present details of the positive effect of IL additives on the electrophilic fluorination of phenols with Selectfluor ${ }^{\mathrm{TM}}$ focusing on the role of ionic species in reactions. The increasingly popular imidazolium- and pyrrolidinium based ionic liquids $[$ Emim $][X]$ (Emim = 1-ethyl-3-methylimidazolium), $[$ Bmim $][X](B m i m=1$-butyl-3-methylimidazolium $)$ and $[$ Pyr] $[X]($ Pyr $=$ pyrrolidinium), especially those with less nucleophilic anions X (Figure 1), have the potential to be ideal promoters of ionic reactions.
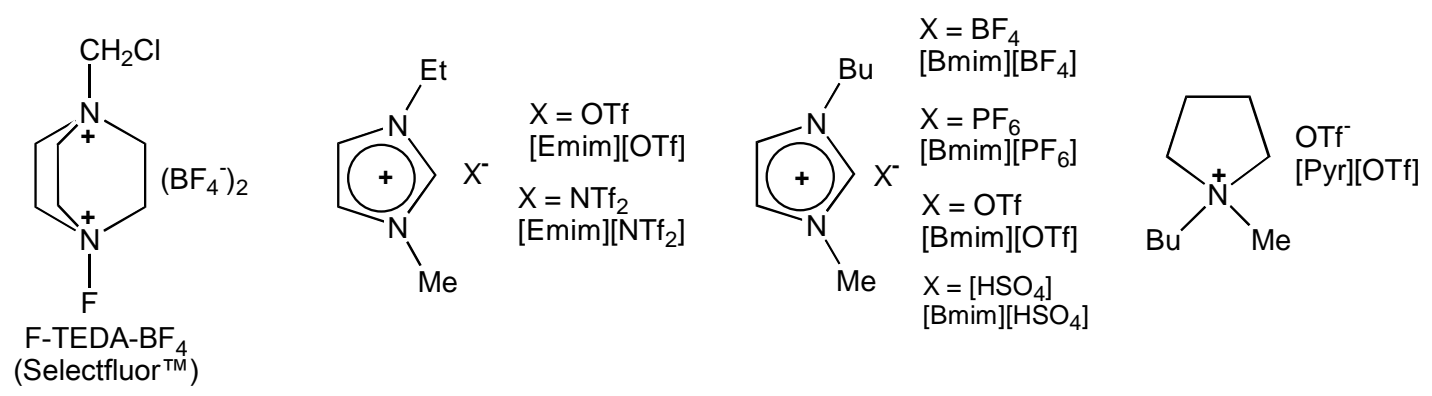

Figure 1. Chemical structures of F-TEDA-BF 4 and the ionic liquids used in this study.

\section{Results and Discussion}

The fluorination of phenol (1) and 1-naphthol (2) with F-TEDA-BF 4 was carried out in various solvents in the presence of a small amount of 1-butyl-3-methylimidazolium ionic liquids ([Bmim][Y]). The reaction of phenols 1 and 2 with F-TEDA-BF 4 (molar ratio F-TEDA-BF 4 /phenol 1.1) gives 2-fluoro-(3), 4-fluorophenol (4), and 2fluoro-(5) and 4-fluoronaphthol (6) as the main products (Schemes 1, 2, Tables 1,2). Minor quantities of difluorides 7-9 are also formed. Quantities of other difluorides in the reaction mixtures were less $0.5 \%$. 


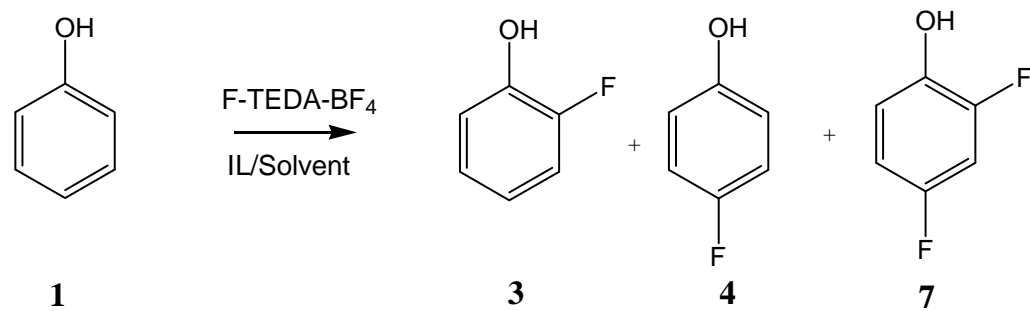

Scheme 1. Reaction of phenol with F-TEDA-BF 4 .<smiles>Oc1cccc2ccccc12</smiles>

2<smiles>Oc1c(F)ccc2ccccc12</smiles>

5<smiles>Oc1ccc(F)c2ccccc12</smiles>

6<smiles>Oc1c(F)cc(F)c2ccccc12</smiles>

8<smiles>O=C1c2ccccc2C=CC1(F)F</smiles>

9

Scheme 2. Reaction of 1-naphthol with F-TEDA-BF 4 .

Table 1. IL effect on the yield of 3,4 and $\mathbf{7}$ in fluorination of phenol with F-TEDA-BF 4 in various solvents ${ }^{\mathrm{a}}$

\begin{tabular}{|c|c|c|c|c|c|c|c|}
\hline \multirow{2}{*}{ Entry } & \multirow{2}{*}{ Solvent } & \multirow{2}{*}{$\varepsilon^{b}$} & \multirow{2}{*}[\mathrm{Bmim}]{$[\mathrm{OTf}] / \mathbf{1}^{\mathrm{c}}$} & \multicolumn{3}{|c|}{ Yield, $\%^{d}$} & \multirow{2}{*}{$\begin{array}{c}\text { Total } \\
\text { yield, \% }\end{array}$} \\
\hline & & & & 3 & 4 & 7 & \\
\hline 1 & $\mathrm{MeNO}_{2}$ & 38.6 & 0 & 0 & 2 & 0 & 2 \\
\hline 2 & $\mathrm{MeNO}_{2}$ & 38.6 & 4 & 33 & 20 & 6 & 59 \\
\hline 3 & $\mathrm{MeCN}$ & 36.2 & 0 & 4 & 12 & 1 & 17 \\
\hline 4 & $\mathrm{MeCN}$ & 36.2 & 4 & 40 & 20 & 7 & 67 \\
\hline 5 & $\mathrm{MeOH}$ & 32.6 & 0 & 0 & 3 & 0 & 3 \\
\hline 6 & $\mathrm{MeOH}$ & 32.6 & 4 & 41 & 24 & 7 & 72 \\
\hline 7 & $\mathrm{EtOH}$ & 24.3 & 0 & 0 & 3 & 0 & 3 \\
\hline 8 & EtOH & 24.3 & 4 & 39 & 25 & 6 & 70 \\
\hline 9 & $i-\mathrm{PrOH}$ & 18.3 & 0 & 2 & 2 & 0 & 4 \\
\hline 10 & $i-\mathrm{PrOH}$ & 18.3 & 4 & 42 & 27 & 5 & 74 \\
\hline 11 & $\left(\mathrm{ClCH}_{2}\right)_{2}$ & 10.4 & 0 & 0.6 & 0.5 & 0 & 1 \\
\hline 12 & $\left(\mathrm{ClCH}_{2}\right)_{2}$ & 10.4 & 4 & 42 & 16 & 7 & 65 \\
\hline 13 & $\mathrm{PhCF}_{3}$ & 9.18 & 0 & 0.4 & 0.2 & 0 & 1 \\
\hline 14 & $\mathrm{PhCF}_{3}$ & 9.18 & 4 & 32 & 20 & 6 & 58 \\
\hline 15 & $\left(\mathrm{Cl}_{2} \mathrm{CH}\right)_{2}$ & 8.2 & 0 & 0 & 0 & 0 & 0 \\
\hline 16 & $\left(\mathrm{Cl}_{2} \mathrm{CH}\right)_{2}$ & 8.2 & 4 & 11 & 10 & 2 & 23 \\
\hline 17 & heptane & 1.92 & 0 & 0 & 0 & 0 & 0 \\
\hline 18 & heptane & 1.92 & 4 & 33 & 22 & 7 & 62 \\
\hline
\end{tabular}

${ }^{\mathrm{a}}$ Reaction conditions: phenol $(0.213 \mathrm{mmol}), \mathrm{F}-\mathrm{TEDA}-\mathrm{BF} 4(0.234 \mathrm{mmol})$, solvent $(5 \mathrm{~mL}), 80{ }^{\circ} \mathrm{C}, 5 \mathrm{~h} .{ }^{\mathrm{b}}$ Dielectric constant of solvent. ${ }^{20 \mathrm{c}}$ Molar ratio. ${ }^{\mathrm{d}}$ Yields determined by ${ }^{19} \mathrm{~F}$ NMR. ${ }^{\mathrm{e}}$ Total yield of fluoro-products. 
It is observed that a small amount of IL strongly influences the selectivity and efficiency of the fluorination reaction (Tables 1, 2). The addition of IL to solvent usually results in acceleration of the reaction. The phenols 1 and 2 react faster with F-TEDA-BF 4 in the presence of the IL providing better yields of fluoro derivatives in comparison to the same reaction without IL. It seems likely that the F-TEDA-BF 4 , being more soluble in the IL, is transferred by it into the solvent and compounds 1 and $\mathbf{2}$ react under these conditions more rapidly. The influence of neat solvent and solvent-IL mixture on total yields of the fluorinated products in the reaction of phenol and 1-naphthol is similar and the solvent polarity usually has a profound effect on the difference in yields of the products obtained in the presence of IL and without it (Tables 1, 2; Figure 2).

It was found that fluorination of 1 -naphthol at $80{ }^{\circ} \mathrm{C}$ when using $[\mathrm{Bmim}]\left[\mathrm{BF}_{4}\right]$ instead of $[\mathrm{Bmim}][\mathrm{OTf}]$ proceeds with the same efficiency (Table 2).

Table 2. IL effect on the yield of 5, 6, 8 and $\mathbf{9}$ in fluorination of 1-naphthol with F-TEDA-BF 4 in various solvents ${ }^{\mathrm{a}}$

\begin{tabular}{|c|c|c|c|c|c|c|c|c|c|}
\hline \multirow{2}{*}{ Entry } & \multirow{2}{*}{ Solvent } & \multirow{2}{*}{$\varepsilon^{b}$} & \multirow{2}{*}[\mathrm{Bmim}]{$[\mathrm{Y}] / \mathbf{2}^{C}$} & \multirow{2}{*}{$Y$} & \multicolumn{4}{|c|}{ Yield, $\%^{d}$} & \multirow{2}{*}{$\begin{array}{c}\text { Total } \\
\text { yield, \% }\end{array}$} \\
\hline & & & & & 5 & 6 & 8 & 9 & \\
\hline 1 & $\mathrm{MeNO}_{2}$ & 38.6 & 0 & - & 23 & 18 & 0.5 & 0.3 & 42 \\
\hline 2 & $\mathrm{MeNO}_{2}$ & 38.6 & 4 & OTf & 34 & 25 & 1 & 7 & 67 \\
\hline 3 & $\mathrm{MeCN}$ & 36.2 & 0 & - & 19 & 20 & 0 & 5 & 44 \\
\hline 4 & $\mathrm{MeCN}$ & 36.2 & 4 & OTf & 34 & 25 & 2 & 7 & 68 \\
\hline 5 & $\mathrm{MeOH}$ & 32.6 & 0 & - & 26 & 16 & 4 & 6 & 52 \\
\hline 6 & $\mathrm{MeOH}$ & 32.6 & 4 & OTf & 35 & 21 & 6 & 9 & 71 \\
\hline 7 & $\mathrm{EtOH}$ & 24.3 & 0 & - & 25 & 17 & 3 & 4 & 49 \\
\hline 8 & $\mathrm{EtOH}$ & 24.3 & 4 & OTf & 34 & 20 & 5 & 6 & 65 \\
\hline 9 & $i$-PrOH & 18.3 & 0 & - & 12 & 10 & 0.5 & 0.8 & 23 \\
\hline 10 & $i-\mathrm{PrOH}$ & 18.3 & 4 & OTf & 32 & 19 & 4 & 5 & 60 \\
\hline 11 & $\left(\mathrm{ClCH}_{2}\right)_{2}$ & 10.4 & 0 & - & 2 & 1 & 0 & 0 & 3 \\
\hline 12 & $\left(\mathrm{ClCH}_{2}\right)_{2}$ & 10.4 & 4 & OTf & 27 & 7 & 3 & 4 & 41 \\
\hline 13 & $\mathrm{PhCF}_{3}$ & 9.18 & 0 & - & 4 & 1 & 0 & 1 & 6 \\
\hline 14 & $\mathrm{PhCF}_{3}$ & 9.18 & 4 & OTf & 28 & 12 & 3 & 3 & 46 \\
\hline 15 & $\left(\mathrm{Cl}_{2} \mathrm{CH}\right)_{2}$ & 8.2 & 0 & - & 3 & 1 & 0 & 0 & 4 \\
\hline 16 & $\left(\mathrm{Cl}_{2} \mathrm{CH}\right)_{2}$ & 8.2 & 4 & OTf & 29 & 7 & 3 & 4 & 43 \\
\hline 17 & heptane & 1.92 & 0 & - & 4 & 2 & 0 & 0.5 & 6 \\
\hline 18 & heptane & 1.92 & 4 & OTf & 25 & 12 & 1 & 2 & 40 \\
\hline 19 & heptane & 1.92 & 4 & $\mathrm{BF}_{4}$ & 28 & 17 & 3 & 2 & 50 \\
\hline 20 & $\mathrm{MeNO}_{2}$ & 38.6 & 4 & $\mathrm{BF}_{4}$ & 32 & 21 & 1 & 5 & 59 \\
\hline 21 & $\mathrm{EtOH}$ & 24.3 & 4 & $\mathrm{BF}_{4}$ & 32 & 20 & 5 & 6 & 63 \\
\hline
\end{tabular}

a Reaction conditions: 1-naphthol $(0.138 \mathrm{mmol})$, F-TEDA-BF $4(0.152 \mathrm{mmol})$, solvent $(5 \mathrm{~mL}), 80{ }^{\circ} \mathrm{C}, 5 \mathrm{~h}$. ${ }^{b}$ Dielectric constant of solvent. ${ }^{20}$ c Molar ratio. ${ }^{\mathrm{d}}$ Yields determined by ${ }^{19} \mathrm{~F}$ NMR. ${ }^{\mathrm{e}}$ Total yield of fluoroproducts. 


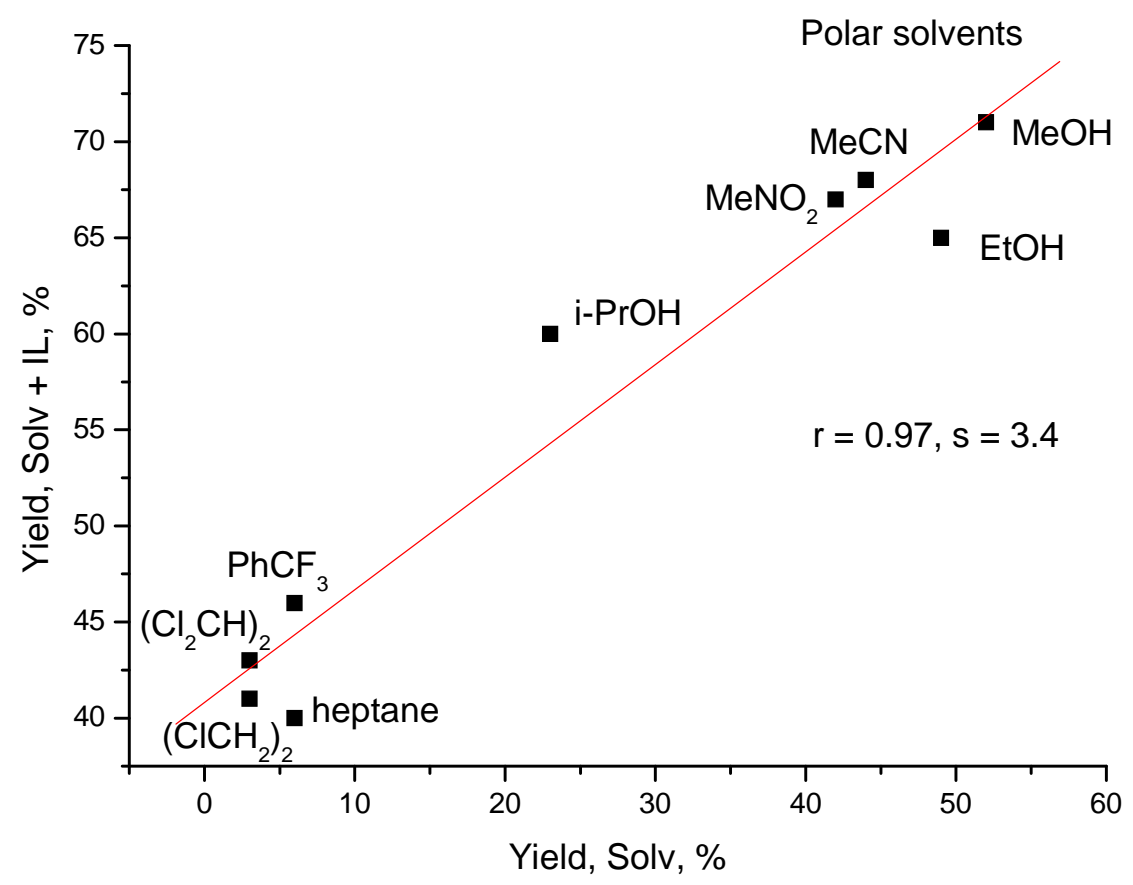

Figure 2. The influence of solvents and solvent-IL mixtures on total yields of the fluorinated products in the reaction of 1-naphthol (2:F-TEDA-BF $4:[B m i m][O T f])=1: 1.1: 4 ; 80^{\circ} \mathrm{C}, 5 \mathrm{~h}$ ).

To develop a more efficient procedure for preparing fluorophenols, we examined the effects of different factors on the fluorination of 2 in $\mathrm{EtOH}$-[Bmim][OTf]. At $80^{\circ} \mathrm{C}$, the rate of the reaction is rather high and the total yield of fluoro-products 5, 6, 8 and 9 reaches $65 \%$. When the temperature is reduced to $40{ }^{\circ} \mathrm{C}$, the yield decreases (Table 2 , entry 8 , Table 3 , entry 1 ), the regioselectivity being unchanged, the ratio of 5/6 remaining practically constant.

Table 3. IL effect on the yield of 5, 6, 8 and 9 in fluorination of 1-naphthol with F-TEDA-BF 4 in EtOH at $40{ }^{\circ} \mathrm{C}^{\mathrm{a}}$

\begin{tabular}{|c|c|c|c|c|c|c|c|c|}
\hline \multirow{2}{*}{ Entry } & \multirow{2}{*}{ IL } & \multirow{2}{*}{$\varepsilon^{\mathrm{b}}$} & \multirow{2}{*}{$\mathrm{IL} / 2^{\mathrm{C}}$} & \multicolumn{4}{|c|}{ Yield, $\%^{d}$} & \multirow{2}{*}{ Total yield, \% ${ }^{\mathrm{e}}$} \\
\hline & & & & 5 & 6 & 8 & 9 & \\
\hline 1 & [Bmim][OTf] & 12.9 & 4 & 29 & 17 & 3 & 3 & 52 \\
\hline 2 & [Bmim][OTf] & 12.9 & 2 & 23 & 13 & 1 & 1 & 38 \\
\hline 3 & {$[\mathrm{Bmim}]\left[\mathrm{BF}_{4}\right]$} & 13.9 & 2 & 11 & 7 & 0.2 & 0.2 & 18 \\
\hline 4 & {$[\mathrm{Bmim}]\left[\mathrm{PF}_{6}\right]$} & 14.0 & 2 & 15 & 9 & 0.5 & 0.6 & 25 \\
\hline 5 & {$[\mathrm{Bmim}]\left[\mathrm{HSO}_{4}\right]$} & - & 2 & 34 & 16 & 5 & 7 & 62 \\
\hline 6 & [Emim][OTf] & 16.5 & 2 & 24 & 14 & 1 & 2 & 41 \\
\hline 7 & {$[$ Emim] $]\left[\mathrm{NTf}_{2}\right]$} & 12.0 & 2 & 24 & 15 & 2 & 2 & 43 \\
\hline 8 & [Pyr][OTf] & - & 2 & 24 & 15 & 2 & 2 & 43 \\
\hline
\end{tabular}

\footnotetext{
${ }^{a}$ Reaction conditions: 1-naphthol $(0.138 \mathrm{mmol}), \mathrm{F}_{-T E D A}-\mathrm{BF}_{4}(0.152 \mathrm{mmol})$, solvent $(5 \mathrm{~mL}), 5 \mathrm{~h}$.

${ }^{b}$ Dielectric constant of IL. ${ }^{21} \mathrm{c}$ Molar ratio. ${ }^{\mathrm{d}}$ Yields determined by ${ }^{19} \mathrm{~F}$ NMR. ${ }^{\mathrm{e}}$ Total yield of fluoroproducts.
} 
In further experiments, the ratio of IL/2 was varied under otherwise similar conditions in various solvents (Figures 3-5).

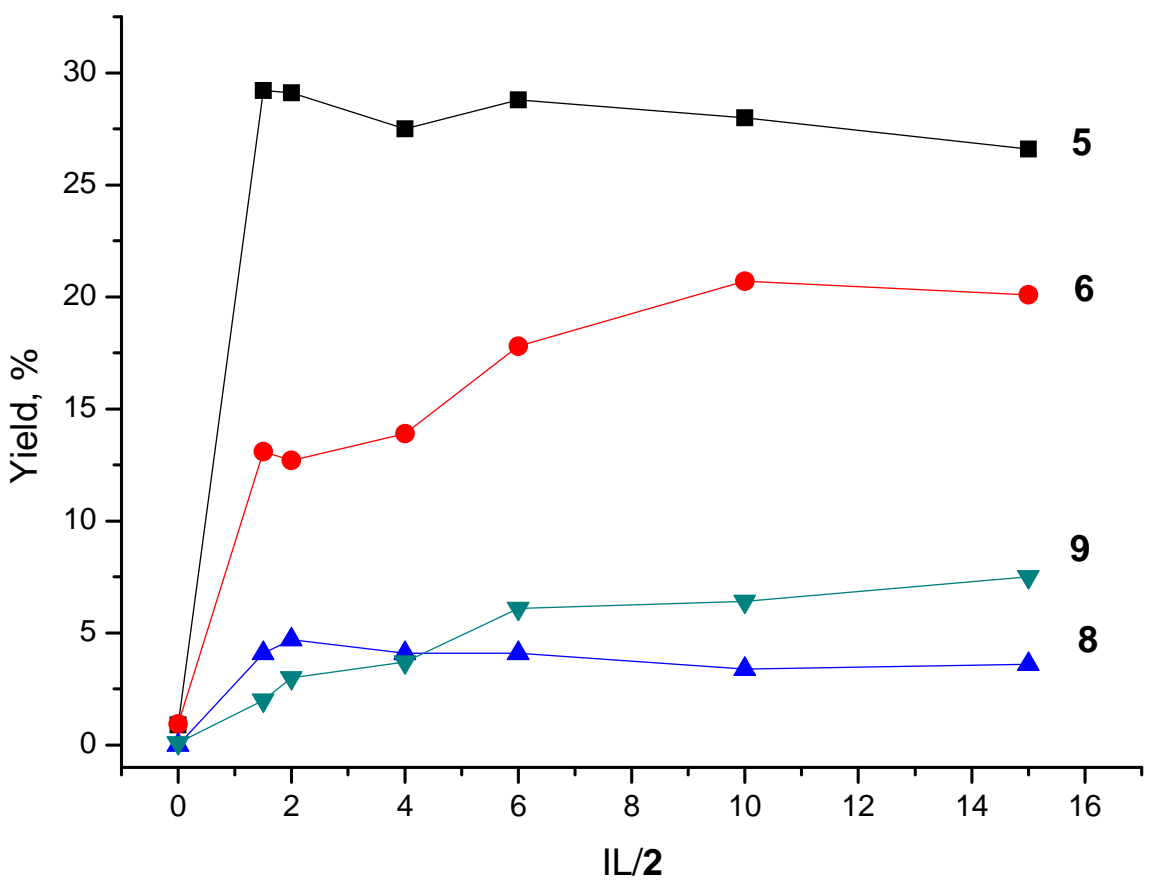

Figure 3. Yields of compound 5, 6, 8 and $\mathbf{9}$ as a function of molar ratio IL/2 (heptane, $\left.80{ }^{\circ} \mathrm{C}, 5 \mathrm{~h}\right)$; ([Bmim][OTf] : $2:$ F-TEDA-BF $4=0-15: 1: 1.1)$.

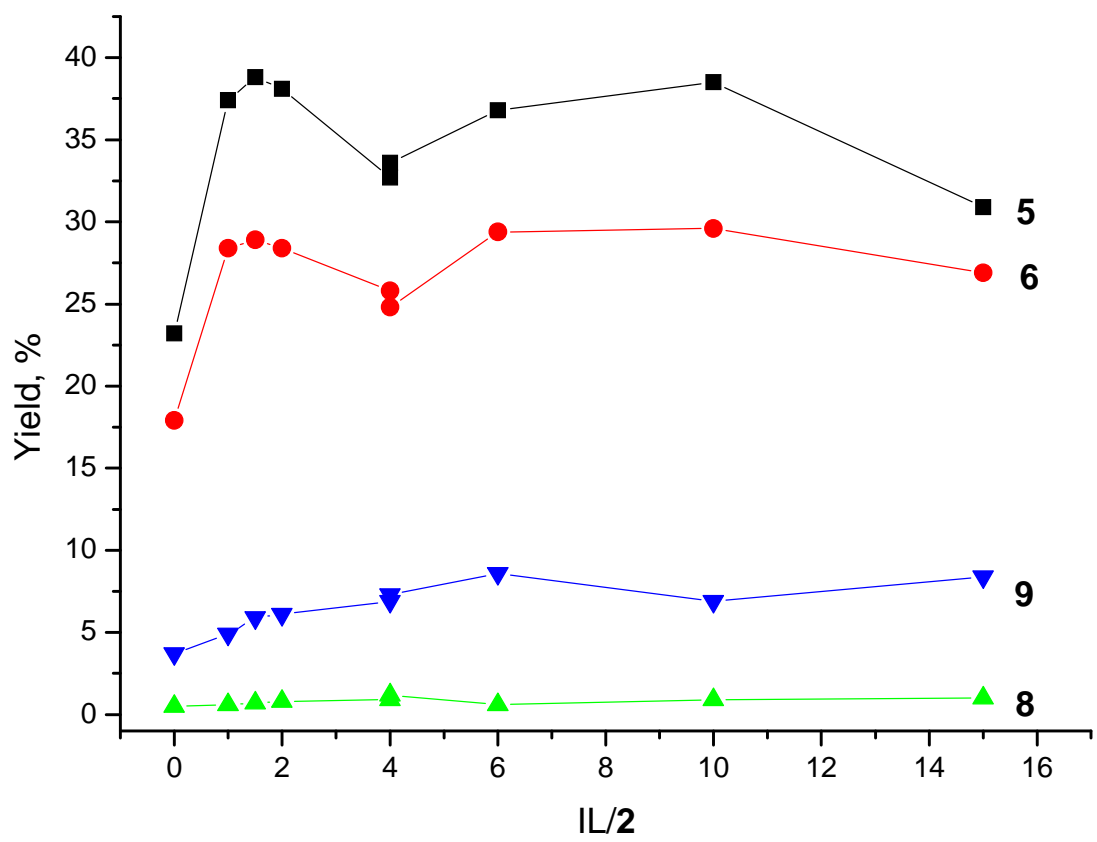

Figure 4. Yields of compound 5, 6, 8 and 9 as a function of molar ratio IL/2 ( $\left.\mathrm{MeNO}_{2}, 80{ }^{\circ} \mathrm{C}, 5 \mathrm{~h}\right)([\mathrm{Bmim}][\mathrm{OTf}]$ : $2:$ F-TEDA-BF $\left._{4}=0-15: 1: 1.1\right)$. 


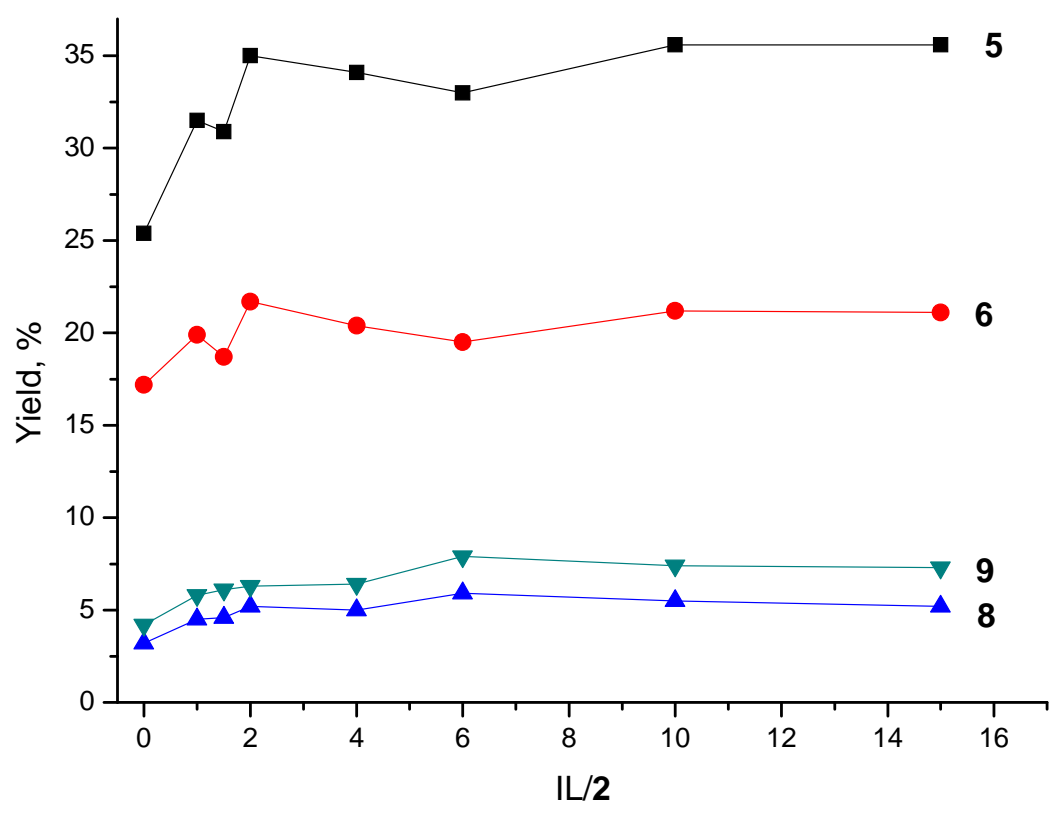

Figure 5. Yields of compound $\mathbf{5 , 6 , 8}$ and $\mathbf{9}$ as a function of molar ratio IL/2 (EtOH, $\left.80{ }^{\circ} \mathrm{C}, 5 \mathrm{~h}\right)$ ([Bmim][OTf]:2:F-

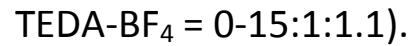

The effect of the ionic liquid is already significant when a molar ratio of IL/2 is 1 . Increase of the IL/2 ratio over 2 does not seem to result in further essential changes in the yield of 5, 6, 8 and $\mathbf{9}$. When IL/2 ratio changes from 2 to 4 , reduction of the yields of $\mathbf{5}$ and $\mathbf{6}$ is usually observed, probably owing to their further fluorination forming 8 and $\mathbf{9}$ (Scheme 3 ).<smiles>Oc1c(F)ccc2ccccc12</smiles>

5<smiles>Oc1ccc(F)c2ccccc12</smiles>

6

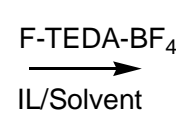<smiles>Oc1c(F)cc(F)c2ccccc12</smiles>

8<smiles>Oc1c(F)ccc2ccccc12</smiles>

5<smiles>OC1c2ccccc2C=CC1(F)F</smiles><smiles>C[PH+]</smiles><smiles>O=C1c2ccccc2C=CC1(F)F</smiles>

9

Scheme 3. Reactions of 5 and $\mathbf{6}$ with F-TEDA-BF 4 .

It was found that the rate of formation of products $5,6,8$ and 9 at lower temperature while using hydrophilic ionic liquids [Bmim][HSO $\left.{ }_{4}\right]$, [Emim][OTf], [Emim][NTf 2 ], [Bmim][OTf], [Pyr][OTf] and EtOH as solvent is much higher than that with $[\mathrm{Bmim}]\left[\mathrm{BF}_{4}\right]$ and $[\mathrm{Bmim}]\left[\mathrm{PF}_{6}\right]$, the efficiency of the anions decreasing in the order of $\left[\mathrm{HSO}_{4}{ }^{-}\right]>[\mathrm{OTf}] \sim\left[\mathrm{NTf}_{2}{ }^{-}\right]>\left[\mathrm{PF}_{6}{ }^{-}\right]>\left[\mathrm{BF}_{4}{ }^{-}\right]$(Table 3). This row generally corresponds to an order of acceptor ability of anions to form $\mathrm{H}$-bond: $\left[\mathrm{HSO}_{4}{ }^{-}\right]>[\mathrm{OTf}]>\left[\mathrm{NTf}_{2}{ }^{-}\right]>\left[\mathrm{PF}_{6}{ }^{-}\right] .{ }^{22}$ The change of the cation part of IL 
has a small influence on the yield of fluorides (Table 3, entries 2, 6, 8). F-TEDA-BF 4 completely dissolves at 80 ${ }^{\circ} \mathrm{C}$ in $\mathrm{MeCN}_{1} \mathrm{MeNO}_{2}$ and only partially in other solvents (MeOH -0.0125 , EtOH $-0.0029, i$-PrOH -0.0001 , $\mathrm{PhCF}_{3}-0.0009,\left(\mathrm{ClCH}_{2}\right)_{2}-0.0026,\left(\mathrm{Cl}_{2} \mathrm{CH}\right)_{2}-0.0002, n$-heptane $\left.-<0.0001 \mathrm{~mol} / \mathrm{L}\right)$. In the case of ionic liquids [Bmim] $\left[\mathrm{HSO}_{4}\right],[\mathrm{Emim}][\mathrm{OTf}],[\mathrm{Emim}]\left[\mathrm{NTf}_{2}\right],[\mathrm{Bmim}][\mathrm{OTf}],[\mathrm{Pyr}][\mathrm{OTf}]$ and $[\mathrm{Bmim}]\left[\mathrm{PF}_{6}\right]$ dissolution of F-TEDA-BF 4 is accompanied obviously by counterion exchange, but this does not create any limitation relative to electrophilic fluorination and even can accelerate reaction by formation of $\mathrm{H}$-bond between $\mathrm{OH}$-group of $\sigma$ complex and counterion. Exception of $\mathrm{EtOH}$ as cosolvent results in a small change in the order of anions: $\left[\mathrm{HSO}_{4}^{-}\right]>\left[\mathrm{OTf}^{-}\right]>\left[\mathrm{NTf}_{2}^{-}\right]>\left[\mathrm{BF}_{4}^{-}\right]>\left[\mathrm{PF}_{6}^{-}\right]$(Table 4). The results clearly show that total yields poorly correlate with the polarity of ionic liquids.

Table 4. IL effect on the yield of 5, 6, 8 and 9 in fluorination of 1-naphthol with F-TEDA-BF 4 at $40{ }^{\circ} \mathrm{C}^{\mathrm{a}}$

\begin{tabular}{|c|c|c|c|c|c|c|c|c|}
\hline \multirow{2}{*}{ Entry } & \multirow{2}{*}{ IL } & \multirow{2}{*}{$\varepsilon^{b}$} & \multirow{2}{*}{$\mathrm{IL} / \mathbf{2}^{\mathrm{C}}$} & \multicolumn{4}{|c|}{ Yield, $\%^{d}$} & \multirow{2}{*}{$\begin{array}{c}\text { Total yield, } \\
\%^{\mathrm{e}}\end{array}$} \\
\hline & & & & 5 & 6 & 8 & 9 & \\
\hline 1 & [Bmim] $[\mathrm{OTf}]$ & 12.9 & 2 & 22 & 13 & 2 & 3 & 40 \\
\hline 2 & {$[\mathrm{Bmim}]\left[\mathrm{BF}_{4}\right]$} & 13.9 & 2 & 14 & 9 & 0.6 & 1 & 25 \\
\hline 3 & {$[\mathrm{Bmim}]\left[\mathrm{PF}_{6}\right]$} & 14.0 & 2 & 7 & 4 & 0.2 & 0.2 & 11 \\
\hline 4 & {$[\mathrm{Bmim}]\left[\mathrm{HSO}_{4}\right]$} & - & 2 & 25 & 11 & 3 & 5 & 44 \\
\hline 5 & [Emim][OTf] & 16.5 & 2 & 21 & 11 & 2 & 4 & 38 \\
\hline 6 & {$[$ Emim $]\left[\mathrm{NTf}_{2}\right]$} & 12.0 & 2 & 17 & 11 & 1 & 2 & 31 \\
\hline 7 & [Pyr][OTf] & - & 2 & 15 & 10 & 1 & 1 & 27 \\
\hline
\end{tabular}

a Reaction conditions: 1-naphthol $(0.138 \mathrm{mmol})$, F-TEDA-BF $4(0.152 \mathrm{mmol}), 5 \mathrm{~h}$. ${ }^{\mathrm{b}}$ Dielectric constant of IL. ${ }^{21}{ }^{\mathrm{c}}$ Molar ratio. ${ }^{\mathrm{d}}$ Yields determined by ${ }^{19} \mathrm{~F} \mathrm{NMR}$. ${ }^{\mathrm{e}}$ Total yield of fluoro-products.

In all cases, the rate of the reaction of 1-naphthol with $\mathrm{F}-\mathrm{TEDA}_{\mathrm{B}} \mathrm{BF}_{4}$ is rather high even with the ratio IL/2 equal to 2 .

Further, we have examined resorcinol (10) as a model for IL-mediated fluoro functionalization with F-TEDA-BF 4 and established that dihydroxybenzenes can also be readily converted into fluoro-derivatives in this way (Scheme 4, Table 5).<smiles>Oc1cccc(O)c1</smiles>

10

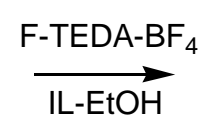

11<smiles>Oc1ccc(F)c(O)c1</smiles><smiles>Oc1cccc(O)c1F</smiles>

12<smiles>Oc1cc(O)c(F)cc1F</smiles>

13

Scheme 4. Reaction of resorcinol with F-TEDA-BF 4 . 
Table 5. IL effect on the yield of 11, 12 and $\mathbf{1 3}$ in fluorination of resorcinol with F-TEDA-BF 4 in EtOH ${ }^{a}$

\begin{tabular}{|c|c|c|c|c|c|c|c|}
\hline \multirow{2}{*}{ Entry } & \multirow{2}{*}{ IL } & \multirow{2}{*}{$\begin{array}{c}\text { Temperature, } \\
{ }^{\circ} \mathrm{C}\end{array}$} & \multirow{2}{*}{$\mathrm{IL} / 10^{\mathrm{b}}$} & \multicolumn{3}{|c|}{ Yield, $\%^{c}$} & \multirow{2}{*}{$\begin{array}{c}\text { Total } \\
\text { yield, \% }\end{array}$} \\
\hline & & & & 11 & 12 & 13 & \\
\hline 1 & - & 24 & 0 & 17 & 0.4 & 0.2 & 18 \\
\hline 2 & [Bmim][OTf] & 24 & 1 & 27 & 1 & 1 & 29 \\
\hline 3 & [Bmim][OTf] & 24 & 2 & 40 & 1 & 2 & 43 \\
\hline 4 & [Bmim][OTf] & 24 & 4 & 51 & 1 & 3 & 55 \\
\hline 5 & [Bmim][OTf] & 24 & 6 & 57 & 2 & 5 & 64 \\
\hline 6 & [Bmim][OTf] & 24 & 10 & 66 & 2 & 8 & 76 \\
\hline 7 & {$[$ Bmim] $][O T f]$} & 24 & 15 & 70 & 2 & 10 & 82 \\
\hline 8 & - & 40 & 0 & 28 & 1 & 1 & 30 \\
\hline 9 & [Bmim] $[\mathrm{OTf}]$ & 40 & 1 & 45 & 1 & 2 & 48 \\
\hline 10 & [Bmim][OTf] & 40 & 2 & 43 & 1 & 2 & 46 \\
\hline 11 & - & 80 & 0 & 59 & 3 & 10 & 72 \\
\hline 12 & [Bmim][OTf] & 80 & 1 & 62 & 3 & 12 & 77 \\
\hline 13 & [Bmim][OTf] & 80 & 2 & 61 & 3 & 11 & 75 \\
\hline 14 & [Bmim][OTf] & 80 & 4 & 64 & 3 & 12 & 79 \\
\hline 15 & {$[$ Bmim] $][\mathrm{OTf}]$} & 80 & 6 & 61 & 3 & 11 & 75 \\
\hline 16 & [Bmim][OTf] & 80 & 10 & 62 & 3 & 12 & 77 \\
\hline 17 & {$[$ Bmim] $][O T f]$} & 80 & 15 & 68 & 3 & 11 & 82 \\
\hline 18 & {$[\mathrm{Bmim}]\left[\mathrm{BF}_{4}\right]$} & 80 & 1 & 68 & 4 & 10 & 82 \\
\hline 19 & {$[\mathrm{Bmim}]\left[\mathrm{BF}_{4}\right]$} & 80 & 2 & 67 & 4 & 9 & 80 \\
\hline
\end{tabular}

${ }^{\mathrm{a}}$ Reaction conditions: resorcinol $(0.182 \mathrm{mmol}), \mathrm{F}-\mathrm{TEDA}-\mathrm{BF} 4(0.200 \mathrm{mmol}), \mathrm{EtOH}(5 \mathrm{~mL}), 5 \mathrm{~h} .{ }^{\mathrm{b}}$ Molar ratio.

${ }^{\mathrm{c}}$ Yields determined by ${ }^{19} \mathrm{~F}$ NMR. ${ }^{\mathrm{d}}$ Total yield of fluoroproducts.

The effect of the ionic liquid is already significant at room temperature when a molar ratio of IL/10 is 1 . Increase of the IL/10 ratio results in further growth of the yield of 11-13 (Figure 6).

At $80{ }^{\circ} \mathrm{C}$, the rate of the reaction is rather high and the yield of fluoro-products $\mathbf{1 1 - 1 3}$ reaches $82 \%$ (Table $5)$. When the temperature is reduced, the total yield of the products decreases but the difference in their yields obtained in the presence of an IL, and without it increases. 


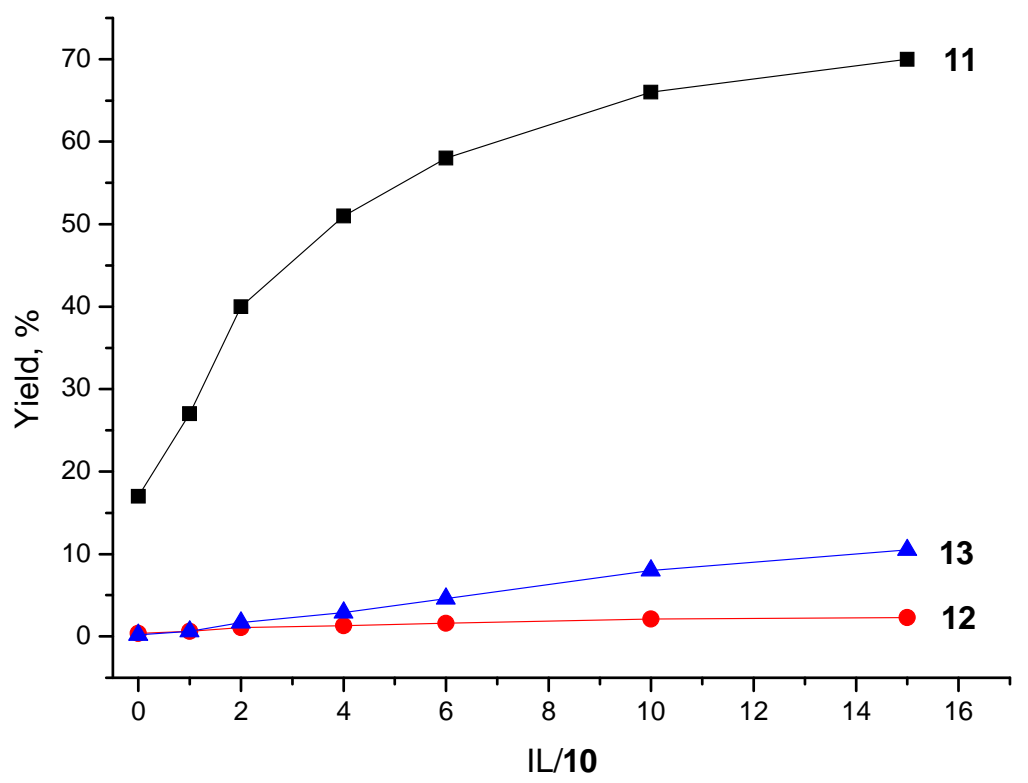

Figure 6. Yields of compound 11-13 as a function of molar ratio IL/10 (EtOH, $\left.24{ }^{\circ} \mathrm{C}, 5 \mathrm{~h}\right)([\mathrm{Bmim}][\mathrm{OTf}]: 10: \mathrm{F}-$

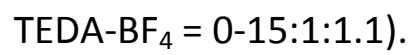

\section{Conclusions}

In summary, we have developed a simple and efficient protocol for the fluorination of phenols with Selectfluor $^{\mathrm{TM}}$ employing a stoichiometric amount of ionic liquid. Addition of a small amount of IL to a solvent enhanced the efficiency of the fluorination. The effect of the nature of the anion of the ionic liquid is more pronounced compared to that of the cation. It has been found that solvent polarity has an essential effect on the difference in yields of fluoro-products obtained in the presence of IL and without it. The cost economy and environmental benefits of using green solvents represent an important contribution to green chemistry.

\section{Experimental Section}

General. Selectfluor ${ }^{\mathrm{TM}}$ and ILs were purchased from Sigma-Aldrich and Acros Organics and used without further purification. The $\mathrm{PhOH}, 1$-naphthol, resorcinol, $n$-heptane and nitromethane were used as obtained commercially. Other organic solvents were dried by standard methods. ${ }^{20}$

The ${ }^{1} \mathrm{H}$ and ${ }^{19} \mathrm{~F}$ NMR spectra were recorded on a Bruker AV-300 spectrometer using the residual proton of deuterated dimethylsulfoxide $\left(\delta_{\mathrm{H}} 2.50 \mathrm{ppm}\right)$ or chloroform $\left(\delta_{\mathrm{H}} 7.24 \mathrm{ppm}\right)$ and $\mathrm{PhCF}_{3}\left(\delta_{\mathrm{F}}-63.73 \mathrm{ppm}\right)$ as internal references. The structures of the compounds obtained were confirmed by ${ }^{1} \mathrm{H}$ and ${ }^{19} \mathrm{~F}$ NMR and GC-MS. The spectral characteristics were consistent with the published data for 2-fluoro-, 4-fluoro-, 2,4difluorophenol ${ }^{23,24}$ 2-fluoro-, 4-fluoro-, 2,4-difluoronaphthalene, 2,2-difluoronaphthalen-1(2H)-one, ${ }^{25,26}$ 2-fluoro-, 4-fluoro- and 4,6-difluoro-resorcinol., 8

General procedure for study of influence of Ils. A mixture of phenol (20 mg), F-TEDA-BF 4 (1.1 equivalents), IL (0-15 equivalents) and the organic solvent $(5 \mathrm{~mL})$ was stirred for $5 \mathrm{~h}$ at various temperatures under an argon 
atmosphere (Tables 1-5). The mixture was evaporated at a reduced pressure and analysed by ${ }^{1} \mathrm{H},{ }^{19} \mathrm{~F} \mathrm{NMR}$ as solution in $\mathrm{CDCl}_{3}$ or $\mathrm{CDCl}_{3}-\mathrm{DMSO}-d_{6} \cdot \mathrm{Cl}_{2} \mathrm{CHCHCl}_{2}$ and $\mathrm{PhCF}_{3}$ were used as internal standards for peak integration.

\section{Acknowledgements}

Spectral and analytical studies were carried out at the Chemical Service Center, Siberian Branch of the Russian Academy of Sciences.

Financial support from the Chemistry and Material Science Department of the Russian Academy of Sciences (project no. 5.1.4) is gratefully acknowledged.

\section{References}

1. Fancelli, D.; Abate, A.; Amici, R.; Bernardi, P.; Ballarini, M.; Cappa, A.; Carenzi, G.; Colombo, A.; Contursi, C.; Di Lisa, F.; Dondio, G.; Gagliardi, S.; Milanesi, E.; Minucci, S.; Pain, G.; Pelicci, P.G.; Saccani, A.; Storto, M.; Thaler, F.; Varasi, M.; Villa M.; Plyte,S. J. Med. Chem., 2014, 57, 5333.

\section{http://dx.doi.org/10.1021/jm500547c}

2. Spadaro, A.; Frotscher, M.; Hartmann, R.W. J. Med. Chem., 2012, 55, 2469.

http://dx.doi.org/10.1021/jm201711b

3. Alexiou, P.; Demopoulos, V. J. J. Med. Chem., 2010, 53, 7756.

http://dx.doi.org/10.1021/jm101008m

4. Isanbor, C.; O'Hagan, D. J. Fluor. Chem., 2006, 127, 303.

http://dx.doi.org/10.1016/j.jfluchem.2006.01.011

5. Liu, X.; Jiang, L.; Li J.,Wang, L.; Yu, Y; Zhou, Q.; Lv, X.; Gong, W.; Lu, Y.; Wang, J. J. Am. Chem. Soc. 2014, 136, 13094.

http://dx.doi.org/10.1021/ja505219r

6. Kitevski-LeBlanc, J.L.; Al-Abdul-Wahid, M.S.; Prosser, R.S. J. Am. Chem. Soc. 2009, 131, 2054. http://dx.doi.org/10.1021/ja8085752

7. Kuo, F; Gillespie, T. A.; Kulanthaivel, P.; Lantz, R.J.; Ma, T.W.; Nelson, D.L.; Threlkeld, P. G.; Wheeler, W. J.; Yi, P.; Zmijewski, M. Bioorg. Med. Chem. Lett. 2004, 14, 3481.

http://dx.doi.org/10.1016/j.bmcl.2004.04.066

8. Sun, W.-C.; Gee, K.R.; Klaubert, D.H.; Haugland, R.P. J. Org. Chem. 1997, 62, 6469.

\section{http://dx.doi.org/10.1021/jo9706178}

9. Kirsch, P. Modern Fluoroorganic Chemistry: Synthesis, Reactivity, Applications, Wiley-VCH, Weinheim, 2013.

10. Uneyama, K. Organofluorine Chemistry, Blackwell: Oxford, 2006.

11. Liang, T; Neumann, C. N.; Ritter, T. Angew. Chem., Int. Ed., 2013, 52, 8214.

http://dx.doi.org/10.1002/anie.201206566

12. Borodkin, G.I.; Shubin, V.G. Russ. Chem. Rev. 2010, 79, 259.

http://dx.doi.org/10.1070/RC2010v079n04ABEH004091

13. Singh, R. P.; Shreeve, J. M. Acc. Chem. Res., 2004, 37, 31.

http://dx.doi.org/10.1021/ar030043v 
14. Laali, K. K.; Borodkin, G. I. J. Chem. Soc., Perkin Trans. 2, 2002, 953. http://dx.doi.org/10.1039/B111725D

15. Baudoux, J.; Salit, A.-F.; Cahard, D.; Plaquevent, J.-C. Tetrahedron Lett., 2002, 43, 6573.

16. Borodkin, G.I.; Zaikin, P.A.; Shubin, V.G. Tetrahedron Lett., 2006, 47, 2639. http://dx.doi.org/10.1016/j.tetlet.2006.02.016

17. Borodkin, G.I.; Zaikin, P.A.; Shakirov, M.M.; Shubin, V.G. Russ. J. Org. Chem., 2007, 43, 1451. http://dx.doi.org/10.1134/S1070428007100077

18. Heravi, M.R.P. J. Fluor. Chem. 2008, 129, 217. http://dx.doi.org/10.1016/j.jfluchem.2007.11.006

19. Borodkin, G.I.; Elanov, I.R.; Gatilov, Y.V.; Shubin, V.G. RSC Adv., 2016, 6, 60556. http://dx.doi.org/10.1039/C6RA10850D

20. Gordon, A.J.; Ford, R.A. The Chemist's Companion. J. Wiley and Sons: New York 1972.

21. Huang, M.-M.; Jiang, Y.; Sasisanker, P.; Driver, G.W.; Weingärtner, H. J. Chem. Eng. Data, 2011, 56, 1494. http://dx.doi.org/10.1021/je101184s

22. Pike, S.J.; Hutchinson, J.J.; Hunter, C.A. J. Am. Chem. Soc., 2017, 139, 6700. http://dx.doi.org/10.1021/jacs.7b02008

23. Singh, S.; DesMarteau, D.D.; Zuberi, S.S.; Witz, M.; Huang, H.-N. J. Am. Chem. Soc., 1987, $109,7194$. http://dx.doi.org/10.1021/ja00257a051

24. Bollard, M.E.; Holmes, E.; Blackledge, C.A.; Lindon, J.C.; Wilson, I.D.; Nicholson, J.K., Xenobiotica, 1996, 26, 255. http://dx.doi.org/10.3109/00498259609046706

25. Zupan, M.; Iskra, J.; Stavber, S. Bull. Chem. Soc. Jpn. 1995, 68, 1655. http://dx.doi.org/10.1246/bcsj.68.1655

26. Stavber, S.; Zupan, M. J. Org. Chem. 1985, 50, 3609.

http://dx.doi.org/10.1021/jo00219a032

27. Umemoto, T.; Nagayoshi, M.; Adachi, K.; Tomizawa, G. J. Org. Chem. 1998, 63, 3379. http://dx.doi.org/10.1021/jo972338q 